Subject coverage is predominantly in the social sciences and history reflecting the particular areas of interest to the Institute. The register excludes materials on education, law, science, technology, linguistics, and literature.

In 1970 theses current at the time were listed in Theses in Progress in Commonwealth Studies which was distributed to all those on the mailing list for the Institute's Accessions List. A further issue appeared in 1971 and a third, due to be published in mid 1972, will incorporate the materials published in the first two. There are tentative plans for publication of the retrospective items though a decision on this is not likely in the immediate future.

Further information can be obtained from The Librarian, Institute of Commonwealth Studies, 27 Russell Square, London, WCiB 5 DS.

\title{
University of Khartoum Library: Theses on the Sudan
}

THE second edition has now appeared of "Theses on the Sudan and by Sudanese accepted for Higher Degrees-Khartoum 1966'. Two hundred new items have been added and several corrections made to the first edition. The list has been rearranged by subject and an author index provided. The subjects covered include: Agriculture, Economics, Education, Geography, History, Language and Literature, Law and Government, Philosophy, Politics, Religion, and Sociology.

\section{'Savanna': a new periodical from Nigeria}

A NEw periodical has recently been published at Ahmadu Bello University, Zaria, Nigeria. Entitled Savanna, and sub-titled 'a journal of the environmental and social sciences', it aims to publish research and comment relating to the savanna region of Nigeria and neighbouring countries. The first issue, for June 1972 , illustrates well its proposed field of interest, containing material on topics in fields as diverse as history, administration, land tenure, education, agriculture, medical geography, geology, and architecture. Each issue of Savanna (which will appear twice yearly in June and December) will contain, in addition to feature articles, an extensive 'Notes and Comments' section, book reviews and conference reports. A special feature is a bibliographic section providing up-to-date information on recent book and periodical publications on the savanna states of Nigeria. The editor is Michael J. Mortimore.

Orders and inquiries should be addressed to Dr. G. J. Williams, Business Manager, Savanna, Ahmadu Bello University, Zaria, Nigeria.

\section{The Kenya Museum Society}

The Kenya Museum Society, which is concerned to promote the museums of Kenya, in December 1971 sponsored and arranged a show of the early hominids found by Richard Leakey east of Lake Rudolf. They also held an exhibition of the Islamic arts of the Kenya coast in February 1972 and published a catalogue entitled Lamu written by James de Vere Allen, Curator of the new Lamu Museum. The exhibition proved so popular that it was later transferred to the first All Africa Trade Fair at Nairobi.

The Society is now publishing a quarterly journal, Kenya Past and Present. The first two issues include articles by Louis Leakey on the history of the National Museum of Nairobi, Jean Brown on cire perdue casting in Kenya, Richard Leakey on current research on man's origin in East Africa, and James Kirkman on the Fort Jesus Museum collection in Mombasa. They have also published a historical guide to Malindi by Esmond Bradley Martin, who is the Society's Chairman. The ex-officio Chairman is Richard E. Leakey, the Administrative Director of the National Museums of Kenya. Individuals and institutions wishing to join 